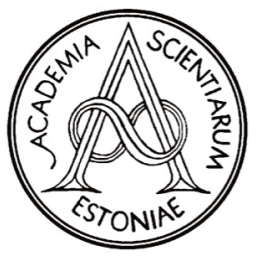

Proceedings of the Estonian Academy of Sciences, $2021,70,2,135-147$

https://doi.org/10.3176/proc.2021.2.01

CATALYTIC

Available online at www.eap.ee/proceedings

CRACKING

\title{
The effect of water and zinc loading on LPG catalytic cracking for light olefin production using Response Surface Methodology
}

\author{
Bijan Barghi* ${ }^{a *}$ Allan Niidu ${ }^{\mathrm{a}}$ and Ramin Karimzadeh ${ }^{\mathrm{b}}$ \\ ${ }^{a}$ School of Engineering, Virumaa College, Tallinn University of Technology, Järveküla tee 75, 30322 Kohtla-Järve, Ida-Viru maakond, \\ Estonia \\ ${ }^{\mathrm{b}}$ Department of Chemical Engineering, Tarbiat Modares University, Jalal Al Ahmad Highway, P.O. Box 14115-111, Tehran, Iran
}

Received 12 December 2020, accepted 22 February 2021, available online 5 April 2021

(C) 2021 Authors. This is an Open Access article distributed under the terms and conditions of the Creative Commons AttributionNonCommercial 4.0 International License (http://creativecommons.org/licenses/by-nc/4.0/).

\begin{abstract}
Optimization of liquefied petroleum gas (LPG) catalytic cracking is one of the most fundamental issues in light olefin production. The Response Surface Methodology (RSM) 5-level-3-factor central composite design (CCD) was used to investigate the effects of zinc loading, water and temperature on ZSM-5 performance. The results show that there is an optimum point for initial propylene and ethylene yields by changing the temperature (from 566 to $634^{\circ} \mathrm{C}$ ) of zinc metal loading in ZSM-5 (from 0.23 to $1.57 \mathrm{wt} \%$ ) and the water/LPG ratio (from 0.32 to 2.68 ), with the yields being $22.34 \mathrm{wt} \%$ and $28.20 \mathrm{wt} \%$, respectively. The experimental data were satisfactorily fitted to quadratic models by using multiple regression analysis over the range of operating conditions. The Response Surface Methodology determined the optimal $\mathrm{Zn}$ loading set $(0.96 \mathrm{wt} \%)$, water/LPG ratio $(1.86)$ and temperature $\left(633.6{ }^{\circ} \mathrm{C}\right)$ to obtain the best result for the initial yields of ethylene and propylene. For ethylene and propylene yield responses, in a quadratic model, F-values showed 15.08 and 54.93, respectively, which states that the models were well-fitted.
\end{abstract}

Key words: water, light olefin yield, modified ZSM-5, catalytic cracking, Response Surface Methodology (RSM).

\section{INTRODUCTION}

Light olefins, propylene and ethylene, are among the largest volumes of petrochemicals, which account for a significant portion of the market demand in the world [1-5]. Due to the limitation of thermal cracking in controlling the olefin product, feed dependence and the global concern about high operating temperatures, catalytic cracking has been taken into account as a traditional method of producing light olefin to overcome the quoted deficiencies [6-8]. Moreover, whilst steam cracking is nowadays carried out in different industries, catalytic cracking at mild temperature in the presence of mild steam as a diluent can be such an efficient alternative

\footnotetext{
*Corresponding author, bibarg@taltech.ee
}

for steam cracking with various feedstocks and high energy consumption [2].

ZSM-5 zeolite has been extensively investigated in various reactions due to the high surface area, acidity, and shape selectivity. This catalyst has been modified in order to adjust acidity and prevent undesirable reactions, which results in a higher light olefin yield. Element modifications have been studied widely by researchers [9-12]. The addition of zinc species into ZSM-5 has made a significant contribution to the conversion rates and selectivity of unsaturated products by enhancing alkanes and alkene dehydrogenation or protolytic cracking [10,13-17]. Zinc cations prevent the hydrogen removal by transferring it to hydrocarbon compounds so as to form light paraffin. The impact of the introduction of $\mathrm{Zn}$ species has been investigated on steamed ZSM-5 in the methanol to aro- 
matics (MTA) and methanol to gasoline (MTG) processes. It is reported that steam treatment lengthens the lifetime and aromatic selectivity of Zn-ZSM-5 catalysts [12,18].

Currently, no investigations have been conducted to examine the catalytic performance of modified HZSM-5 by means of the RSM approach. For this purpose, a CCD methodology is applied to obtain a statistical model of the yield of light olefins. Herein, for the first time, we have employed the aforesaid method to optimize the three significant factors in the catalyst design of HZSM-5 for the cracking of LPG: water in the feed, zinc loading in the catalyst, and temperature on light olefins yields.

\section{EXPERIMENTAL}

\subsection{Material}

Na-ZSM-5 $\left(\mathrm{SiO}_{2} / \mathrm{Al}_{2} \mathrm{O}_{3}\right.$ ratio: 38 , specific surface area: $320 \mathrm{~m}^{2} \mathrm{~g}^{-1}$, mesopore volume: $0.14 \mathrm{~cm}^{3} \mathrm{~g}^{-1}$ ) was purchased from Alibaba.com (Hangzhou, China) and used as a parent catalyst $\mathrm{Zn}\left(\mathrm{NO}_{3}\right)_{2} \cdot 6 \mathrm{H}_{2} \mathrm{O}(0.0050 \mathrm{M}$, Aldrich, $>98.0 \%$ ). Ammonium nitrate (from Merck, Darmstadt, Germany; $>99 \%$ ) was applied for the impregnation of the catalyst.

\subsection{Catalyst preparation}

To achieve H-ZSM-5, Na-ZSM-5 was ion-exchanged with $1 \mathrm{M} \mathrm{NH}_{4} \mathrm{NO}_{3}$ for 3 hours, at $80{ }^{\circ} \mathrm{C}$. This procedure was repeated three times so as to complete the extraction of $\mathrm{Na}^{+}$ions and the replacement of protons. The sample was then filtered, washed, and dried at $110^{\circ} \mathrm{C}$ for $12 \mathrm{~h}$, and finally calcined at $550{ }^{\circ} \mathrm{C}$ for $4 \mathrm{~h}$ in a continuous supply of air. The respective catalyst samples including various zinc species were prepared by the wet impregnation method. To this end, $\mathrm{Zn}\left(\mathrm{NO}_{3}\right)_{2} \cdot 6 \mathrm{H}_{2} \mathrm{O}$ aqueous solutions were made in five different amounts to prepare $\mathrm{xZn}$ ZSM-5, in which $\mathrm{x}$ denotes the weight percentage of $\mathrm{Zn}$ content, which was as follows: $0.23,0.5,0.9,1.3$ and $1.57 \mathrm{wt} \%$. The slurry was stirred at $25-30{ }^{\circ} \mathrm{C}$ for $4 \mathrm{~h}$, then evaporated in a rotary evaporator at $68^{\circ} \mathrm{C}$ until the water was removed. Thereafter, the catalyst was dried at $110^{\circ} \mathrm{C}$ for $12 \mathrm{~h}$ in an oven and calcined in a furnace at $650{ }^{\circ} \mathrm{C}$ for $3 \mathrm{~h}[19]$.

\subsection{Characterization}

X-ray diffraction analysis (XRD) was performed by a PHILIPS PW 3719 X-ray diffractometer in order to illustrate the specification of crystallinity and the structure of samples. Using $\mathrm{Cu}-\mathrm{K} \alpha$ radiation $(40 \mathrm{kV}, 40 \mathrm{~mA}$, $\lambda=1.78897 \AA$ ), the diffraction peaks were recorded in the $2 \theta$ range of $5-65^{\circ}$, with an angular step size of 0.04 . The surface properties and identification of functional groups were determined by Fourier Transform Infrared (FTIR) spectroscopy. In this analysis, the samples were blended with potassium bromide powder and then pressed under high pressure. Following this, the extracted pellet was inserted into a holder at the spectrometer, and the IR spectrum was recorded.

\subsection{Activation procedure}

A fixed-bed tubular reactor with an internal diameter of $10 \mathrm{~mm}$ and $500 \mathrm{~mm}$ was used for LPG catalytic cracking tests. The amount of the powder catalyst $(0.1-0.2 \mathrm{~mm}$ diameter) in each test was $0.09-0.13 \mathrm{~g}$, which was diluted by Pyrex quartz beads. The catalyst was located at the length of $300 \mathrm{~mm}$ from the inlet of the reactor surrounded by quartz wools. The reaction temperature was measured by a thermocouple attached to the wall across the axis of the catalyst bed. For the initial step, the catalyst sample was heated by air in $40 \mathrm{~cm}^{3} / \mathrm{min}$ volume flow with the step of $10^{\circ} \mathrm{C} / \mathrm{min}$ for $1 \mathrm{~h}$. Thereafter, the tubular reactor was purged by pure $\mathrm{N}_{2}$ gas for $1 \mathrm{~h}$ at the desired temperature. Finally, the LPG feed was crossed from the sample catalyst (LPG includes $45.7 \mathrm{wt} \%$ propane, $20.6 \mathrm{wt} \%$ i-butane, $29.1 \mathrm{wt} \% \mathrm{n}$-butane and $4.6 \mathrm{wt} \%$ impurities). The reaction temperature was in the range of $566-634^{\circ} \mathrm{C}$ at atmospheric pressure. The nitrogen gas, steam, and feedstock were all supplied simultaneously during the operation. Steam was introduced to the reactor feed stream using a regulating syringe pump in five different values. The products (cracking outlet) were analysed by means of a fast refinery gas analyser (RGA) Agilent model 7890A. Before entering the gas chromatograph (GC), the product was passed through a condenser to separate the liquid from the gaseous products. Considering the condition that the product analysis was performed within the first 20 minutes of the reaction, catalyst deactivation in the modelling of this process was neglected. Since the catalytic cracking process was a highly endothermic reaction, in order to achieve the isothermal condition, the catalyst of 60 mesh size was diluted in the Pyrex quartz beads (six times of the amount of the catalyst) of 60 mesh size. In the current study, the ratio between the catalyst bed height and the particle size (35-50) and the ratio of the reactor internal diameter to the catalyst particle size (10-30) were sufficiently high to avoid channeling, back-mixing of plug flow and internal mass transfer limitation. For removing the external mass transfer limitation, more than $6 \mathrm{~mL} / \mathrm{min}$ of the feed (LPG) flow rate at $400 \mathrm{~mL} /(\mathrm{min} . \mathrm{g})$ GHSV (Gas Hourly Space Velocity) was appropriate. Thus, the surface reaction can be considered to be the rate-controlling step. The flow rate of feeds was controlled by the mass flow controller (MFC). The reactor setup is depicted in Fig. 1. 
Programmable

temperature controller

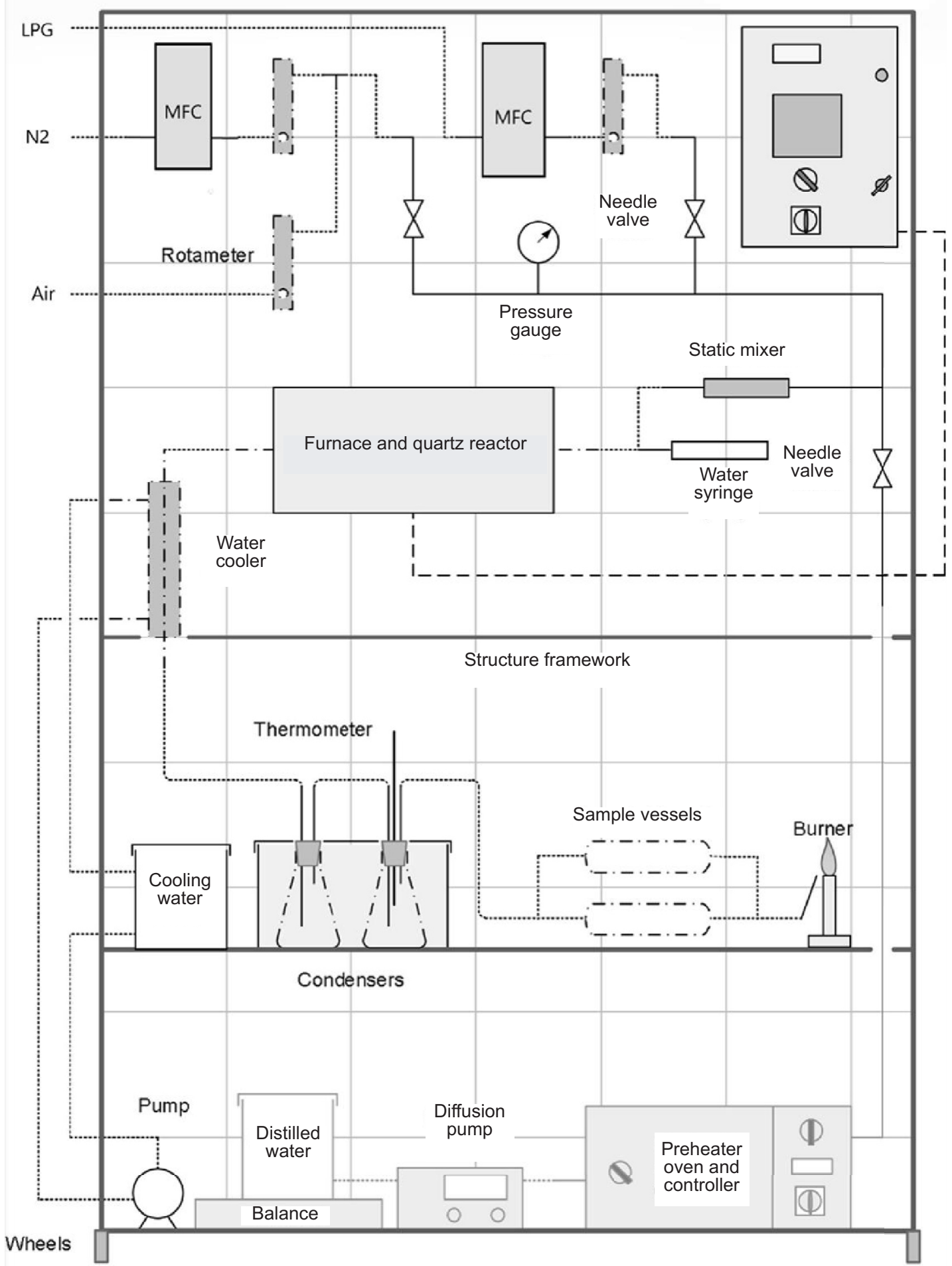

Line legend:

Steel:

Glass: $-\cdot \cdot \cdot \cdot \cdot-$

Silicon:

Cable: -----

Fig. 1. Schematic of the catalytic cracking reactor setup. 


\section{NUMERICAL METHOD}

In statistical design, the CCD in the RSM is a modelling method employed to study and analyse the correlation between a set of adjustable factors and obtained responses. Thus, the results of the CCD were applied to ascertain the effect of the three following parameters: temperature (566.4-633.6 $\left.{ }^{\circ} \mathrm{C}, \mathrm{X}_{1}\right)$, steam ratio $\left(0.8-2.2, \mathrm{X}_{2}\right)$, and $\mathrm{Zn}$ loading $\left(0.23-1.57 \mathrm{wt} \%, \mathrm{X}_{3}\right)$ on ethylene and propylene yields $\left(\mathrm{Y}_{1}, \mathrm{Y}_{2}\right.$, respectively). Following this, seventeen treatments were conducted at five levels: $-1.68,-1,0,1$, and 1.68 , as shown in Table 1 . To evaluate the repeatability of the model, the center point was repeated three times. For statistical calculations, the relation between the coded values and the actual ones is described by Equation (1):

$$
Y=\beta_{0}+\sum_{i=1}^{3} \beta_{i} X_{i}+\sum_{i=1}^{3} \sum_{j=1}^{3} \beta_{i j} X_{i} X_{j}+\varepsilon,
$$

where $X_{i}$ and $X_{j}$ are variables, $Y$ represents the predicted response, $\beta_{0}$ is a constant term, $\beta_{j}$ the coefficient of the linear terms, $\beta_{i j}$ the coefficient of the interaction terms, and $\varepsilon$ is the residual related to the experiments. The experiments $(\mathrm{N})$ are determined by the following Equation (2):

$$
N=2^{k}+2^{k}+n_{0},
$$

where $k$ is the number of independent parameters; $2^{k}$ is the number of experiments for the variables having the code value equal to \pm 1 (factorial points); $2 * k$ is the number of experiments for the variables with the code value equal to $\pm \alpha$ (axial points), and $n_{0}$ is the number of experiments for the variables having a code value equal to 0 (central point). The experiment $n_{0}$ was taken three times. Therefore, the total of 17 runs were performed in this study with the coded factor levels of the three variables [20].

\section{RESULTS AND DISCUSSION}

\subsection{Characterization results}

As can be seen in Fig. 2, all Zn-ZSM-5 samples illustrate two characteristic peaks between $2 \theta=7-9^{\circ}$ and $23-25^{\circ}$, corresponding to a preserved ZSM-5 structure. X-ray patterns show that the Zn-ZSM-5 catalyst maintains the

Table 1. Independent test variables at five different levels used for catalytic cracking according to the CCD

\begin{tabular}{l|c|c|c|c|c|c|c}
\hline \multirow{2}{*}{ Factor } & \multirow{2}{*}{ Unit } & Code & \multicolumn{5}{|c}{ Real values of coded levels } \\
\cline { 4 - 8 } & & & $\begin{array}{c}\text { Low axial } \\
\left(-\alpha^{*}\right)\end{array}$ & $\begin{array}{c}\text { Low } \\
\text { factorial } \\
(-1)\end{array}$ & $\begin{array}{c}\text { Center point } \\
(0)\end{array}$ & $\begin{array}{c}\text { High } \\
\text { factorial } \\
(+1)\end{array}$ & $\begin{array}{c}\text { High axial } \\
\left(+\alpha^{*}\right)\end{array}$ \\
\hline Temperature & & & & & & & \\
Steam/LPG ratio in feed & - & $\mathrm{C}$ & 566.4 & 580.0 & 600.0 & 620.0 & 633.6 \\
Zn content & & 0.32 & 0.80 & 1.50 & 2.20 & 2.68 \\
\hline
\end{tabular}

${ }^{*} \alpha: 1.68$.

Note: Standard uncertainties $(\mathrm{u})$ are $\mathrm{u}(\mathrm{T})= \pm 0.1^{\circ} \mathrm{C} ; \mathrm{u}($ Steam ratio $)= \pm 0.01 ; \mathrm{u}(\mathrm{Zn}$ content $)= \pm 0.01 \mathrm{wt} \%$.

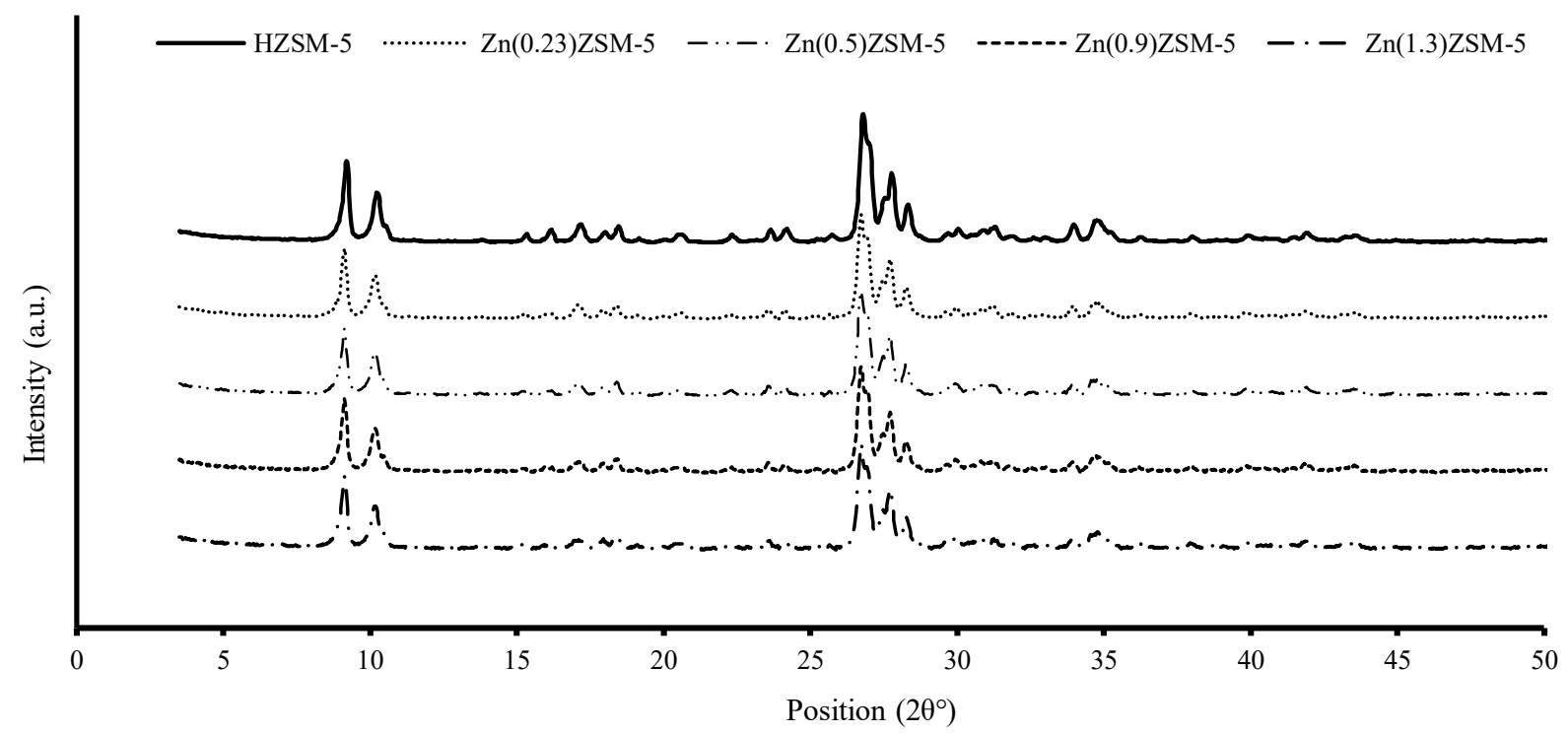

Fig. 2. XRD patterns of the parent HZSM-5 and Zn/ZSM-5 in $0.23,0.5,0.9,1.3 \mathrm{wt} \%$ loading in HZSM-5. 


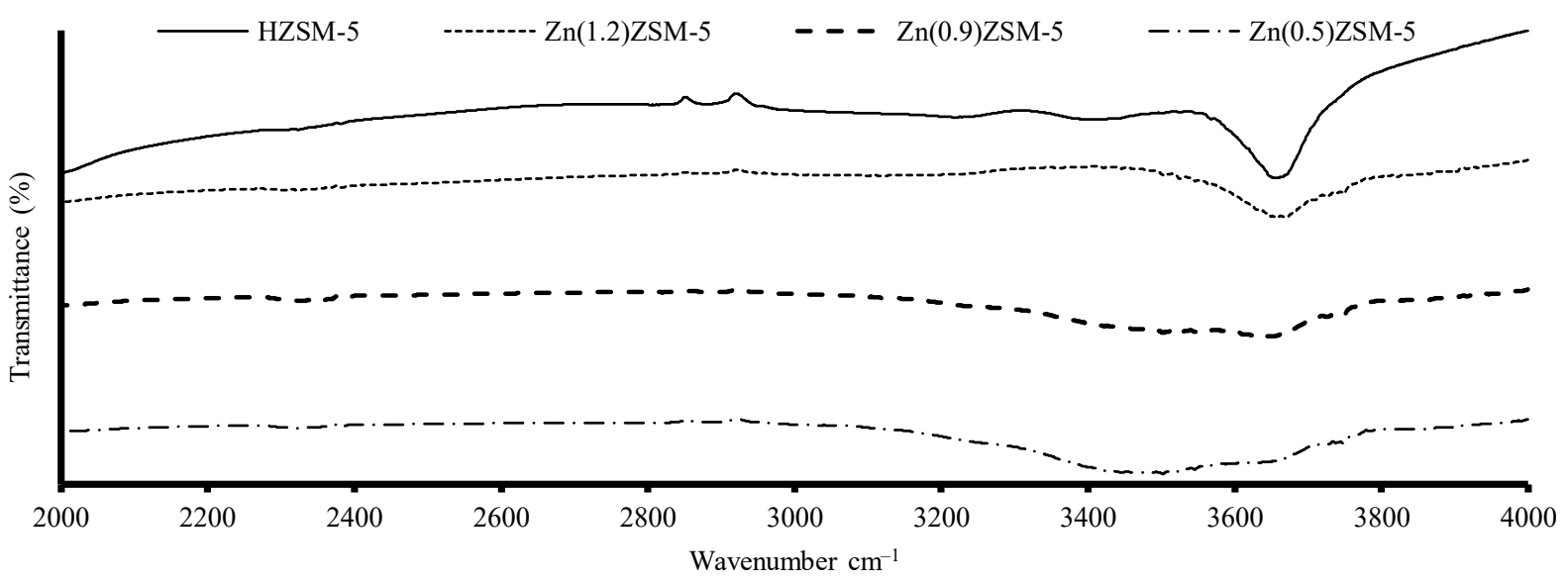

Fig. 3. Infrared spectra of the parent HZSM-5 and Zn/ZSM-5 in 0.5, 0.9, $1.3 \mathrm{wt} \%$ loading in HZSM-5.

structure of the parent HZMS-5, there were no peaks of impurities and other obvious crystalline defects for the Zn-HZSM-5 samples in comparison with the HZSM-5 catalyst $[18,21]$.

The FTIR spectra of the Zn-ZSM-5 samples are demonstrated in Fig. 3. According to Fig. 3, the alkaline introduction of zinc resulted in an increase in the relative intensity of the band between $3740-3747 \mathrm{~cm}^{-1}$, which corresponded to terminal silanol groups. It can be observed that the introduction of zinc in an amount more than $0.9 \mathrm{wt} \%$ did not have a significant difference in the peak increase. This external silanol provided the extra strong acidic site for dehydrogenation and cracking. With the band at $3728 \mathrm{~cm}^{-1}$, being assigned to silanol sites, located inside the zeolite structure, three ZnZSM-5 samples had almost the same intensity [22,23]. There was a clear shoulder around $3660 \mathrm{~cm}^{-1}$, corresponding to the presence of $\mathrm{OH}$ group for octahedral non-framework aluminum sites.

\subsection{Result of LPG catalytic cracking}

The experiments were conducted under the specified experimental conditions based on the CCD model. The consequences of the key factors ( $\mathrm{Zn}$ loading, steam ratio, and temperature) were studied at the beginning of the reaction. The analysis was performed by the Design-Expert 11 software. The matrix design as well as the experimental results are illustrated in Table 2. Experiments 8, 13 and 16 were central points.

Tables 3 and 4 show the analysis of the variance (ANOVA) for the experimental variables as linear, quadratic and interaction terms of each response variable and the corresponding coefficients for the predictive models of ethylene and propylene, respectively.

For ethylene and propylene yield responses, the quadratic model was selected. After the analysis, F-values were obtained as 15.08 and 54.93, respectively, which stated that the models were fitted. P-values of less than $0.001(0.0009$ and $<0.0001)$ showed that the fitted models were significant at the $99.9 \%$ confidence level.

\subsection{Fitting models and adequacy survey}

The quadratic order for the initial yields of ethylene and propylene are presented in Equations (3) and (4):

$$
\begin{aligned}
& \text { Ethylene yield }(w t \%) \\
& =23.44+2.18 A+0.47 B+0.043 C+0.22 A B \\
& \quad+0.071 A C+0.03 B C+0.27 A^{2}-0.48 B^{2}-0.61 C^{2} ; \\
& \text { Propylene yield }(w t \%) \\
& =17.40+2.65 A-0.038 B-0.068 C-0.069 A B \\
& \quad-0.075 A C+0.070 B C+0.28 A^{2}-0.13 B^{2}-0.62 C^{2},
\end{aligned}
$$

where $A, B$ and $C$ are temperature, steam ratio, and $\mathrm{Zn}$ content in the zeolite catalyst, respectively. The multiple letters represent the interaction between factors. The coefficients of determination $\left(\mathrm{R}^{2}\right)$ values of 0.951 and 0.986 were obtained for ethylene and propylene yields, in turn. It demonstrated that the quadratic model was suitable for representing the system under the experimental results.

\subsection{Effect of main factors}

The catalytic performance of modified ZSM-5 in the cracking of LPG was studied in a conventional reaction. The temperature $\left({ }^{\circ} \mathrm{C}\right)$, loading of zinc over HZSM-5 (wt $\%$ ), steam to LPG ratio (-) changed between $566-634{ }^{\circ} \mathrm{C}$, $0.23-1.57 \mathrm{wt} \%$, and $0.32-2.68$, respectively. Figures 4 and 5 present the model predicted yields of ethylene and propylene, respectively, for different temperatures. Figures $4 \mathrm{a}$ and $5 \mathrm{a}$ illustrate the effect of temperature on olefin yields for different steam to LPG ratios at the constant $0.9 \mathrm{wt} \% \mathrm{Zn}$ loading to HZSM-5. For both olefin yields, the steam ratio contribution was not significant in 
Table 2. Design matrix and experimental results using CCP

\begin{tabular}{|c|c|c|c|c|c|c|c|c|c|c|c|c|}
\hline \multirow[t]{2}{*}{ Run } & \multicolumn{3}{|c|}{ Factor } & \multirow{2}{*}{$\begin{array}{c}\begin{array}{c}\text { Yield } \\
(\mathrm{wt} \%)\end{array} \\
\text { Ethylene }\end{array}$} & \multirow{2}{*}{\begin{tabular}{|c|}
$\begin{array}{c}\text { Yield } \\
(\mathrm{wt} \%)\end{array}$ \\
Propylene
\end{tabular}} & \multirow{2}{*}{\begin{tabular}{|c|}
$\begin{array}{c}\text { Yield } \\
\left(\mathrm{wt}^{0} \%\right)\end{array}$ \\
Methane
\end{tabular}} & \multirow{2}{*}{\begin{tabular}{|l|}
$\begin{array}{l}\text { Yield } \\
(\mathrm{wt} \%)\end{array}$ \\
Ethane \\
\end{tabular}} & \multirow{2}{*}{\begin{tabular}{|c|}
$\begin{array}{c}\text { Yield } \\
(\mathrm{wt} \%)\end{array}$ \\
Propane \\
\end{tabular}} & \multirow{2}{*}{\begin{tabular}{|c|}
$\begin{array}{c}\text { Yield } \\
(\mathrm{wt} \%)\end{array}$ \\
$\begin{array}{c}\text { Butane } \\
(\mathrm{i}, \mathrm{n})\end{array}$
\end{tabular}} & \multirow{2}{*}{\begin{tabular}{|c|c|}
$\begin{array}{c}\text { Yield } \\
(w t \%)\end{array}$ \\
Hydrogen
\end{tabular}} & \multirow{2}{*}{\begin{tabular}{|c|}
$\begin{array}{c}\text { Yield } \\
(\mathrm{wt} \%)\end{array}$ \\
$\begin{array}{c}\text { Butylenes } \\
(\mathrm{i}, \mathrm{n}, \mathrm{t}, \mathrm{c})\end{array}$
\end{tabular}} & \multirow{2}{*}{$\begin{array}{r}\begin{array}{r}\text { Yield } \\
(\mathrm{wt} \%)\end{array} \\
\mathrm{C}^{+}{ }_{5}\end{array}$} \\
\hline & $\begin{array}{c}\mathrm{A}: \\
\text { Temperature } \\
{ }^{\circ} \mathrm{C}\end{array}$ & $\begin{array}{c}\text { B: } \\
\text { Steam } \\
\text { ratio }\end{array}$ & $\begin{array}{c}\mathrm{C}: \\
\mathrm{Zn} \\
\text { content } \\
\mathrm{wt} \% \\
\end{array}$ & & & & & & & & & \\
\hline 1 & 566.4 & 1.50 & 0.90 & 20.09 & 14.09 & 8.18 & 5.31 & 6.84 & 25.96 & 2.61 & 5.35 & 4.36 \\
\hline 2 & 620.0 & 2.20 & 0.50 & 24.65 & 19.76 & 8.20 & 4.84 & 5.67 & 26.80 & 2.63 & 6.31 & 3.33 \\
\hline 3 & 600.0 & 0.32 & 0.90 & 21.71 & 16.99 & 13.65 & 7.69 & 6.88 & 10.31 & 3.08 & 5.72 & 4.72 \\
\hline 4 & 580.0 & 0.80 & 1.30 & 20.27 & 14.13 & 14.46 & 7.67 & 5.74 & 10.80 & 3.10 & 6.97 & 4.57 \\
\hline 5 & 600.0 & 1.50 & 0.23 & 22.10 & 16.00 & 10.64 & 6.20 & 6.68 & 21.82 & 2.84 & 6.40 & 4.60 \\
\hline 6 & 600.0 & 2.68 & 0.90 & 23.24 & 16.86 & 10.51 & 6.03 & 6.48 & 21.80 & 2.80 & 5.78 & 4.44 \\
\hline 7 & 620.0 & 0.80 & 1.30 & 23.55 & 20.00 & 14.68 & 7.86 & 6.49 & 8.74 & 3.16 & 6.34 & 4.22 \\
\hline 8 & 600.0 & 1.50 & 0.90 & 23.51 & 17.56 & 11.31 & 7.13 & 6.05 & 18.07 & 2.74 & 6.38 & 4.42 \\
\hline 9 & 600.0 & 1.50 & 1.57 & 22.10 & 15.03 & 10.95 & 6.27 & 6.13 & 21.17 & 2.91 & 5.77 & 3.99 \\
\hline 10 & 620.0 & 0.80 & 0.50 & 23.40 & 19.91 & 7.79 & 4.46 & 6.61 & 25.40 & 2.61 & 5.97 & 4.60 \\
\hline 11 & 580.0 & 2.20 & 1.30 & 20.77 & 14.53 & 12.66 & 7.43 & 6.53 & 12.59 & 2.93 & 6.62 & 4.65 \\
\hline 12 & 633.6 & 1.50 & 0.90 & 29.09 & 22.07 & 14.70 & 8.01 & 3.20 & 10.08 & 2.29 & 5.63 & 4.99 \\
\hline 13 & 600.0 & 1.50 & 0.90 & 23.41 & 17.44 & 11.86 & 6.93 & 6.46 & 16.88 & 2.93 & 5.91 & 4.33 \\
\hline 14 & 580.0 & 0.80 & 0.50 & 20.25 & 14.14 & 9.96 & 6.55 & 7.34 & 22.73 & 2.79 & 5.63 & 4.64 \\
\hline 15 & 580.0 & 2.20 & 0.50 & 20.78 & 13.87 & 9.27 & 5.60 & 6.41 & 24.60 & 2.71 & 5.74 & 4.59 \\
\hline 16 & 600.0 & 1.50 & 0.90 & 23.26 & 17.23 & 11.45 & 7.42 & 6.69 & 17.54 & 2.89 & 5.93 & 4.16 \\
\hline 17 & 620.0 & 2.20 & 1.30 & 25.08 & 19.73 & 14.24 & 7.89 & 6.05 & 10.91 & 3.08 & 6.39 & 5.05 \\
\hline
\end{tabular}

Table 3. Analysis of variance results for the ethylene yield from Response Surface Quadratic Model

\begin{tabular}{lcc|c|c|c}
\hline \multicolumn{1}{c}{ Source } & Sum of squares & Df & Mean square & F-value & p-value prob $>$ F \\
\hline A: Temperature $\left({ }^{\circ} \mathrm{C}\right)$ & 64.71 & 1 & 64.72 & 114.08 & $<0.0001$ \\
B: Steam ratio $(-)$ & 2.98 & 1 & 2.99 & 5.27 & 0.055 \\
C: Zn content $\left(\mathrm{wt}^{\circ} \%\right)$ & 0.02 & 1 & 0.0251 & 0.04 & 0.839 \\
$\mathrm{AB}$ & 0.37 & 1 & 0.38 & 0.67 & 0.440 \\
$\mathrm{AC}$ & 0.04 & 1 & 0.041 & 0.07 & 0.796 \\
$\mathrm{BC}$ & 0.007 & 1 & 0.007 & 0.013 & 0.913 \\
$\mathrm{~A}^{2}$ & 0.83 & 1 & 0.83 & 1.46 & 0.267 \\
$\mathrm{~B}^{2}$ & 2.57 & 1 & 2.57 & 4.53 & 0.071 \\
$\mathrm{C}^{2}$ & 4.22 & 1 & 4.22 & 7.44 & 0.029 \\
Model & 76.98 & 9 & 8.55 & 15.08 & 0.0009 \\
Error & 0.034 & 2 & 0.017 & &
\end{tabular}

Table 4. Analysis of variance results for the propylene yield from Response Surface Quadratic Model

\begin{tabular}{lcccccc}
\hline \multicolumn{1}{c}{ Source } & Sum of squares & Df & Mean square & F-value & p-value prob $>$ F \\
\hline A: Temperature $\left({ }^{\circ} \mathrm{C}\right)$ & 95.77 & 1 & 95.77 & 459.21 & $<0.0001$ \\
B: Steam ratio $(-)$ & 0.019 & 1 & 0.019 & 0.093 & 0.769 \\
C: Zn content (wt \%) & 0.064 & 1 & 0.064 & 0.305 & 0.598 \\
$\mathrm{AB}$ & 0.038 & 1 & 0.038 & 0.1844 & 0.681 \\
$\mathrm{AC}$ & 0.045 & 1 & 0.045 & 0.218 & 0.655 \\
$\mathrm{BC}$ & 0.039 & 1 & 0.039 & 0.188 & 0.678 \\
$\mathrm{~A}^{2}$ & 0.900 & 1 & 0.900 & 4.31 & 0.076 \\
$\mathrm{~B}^{2}$ & 0.179 & 1 & 0.179 & 0.861 & 0.384 \\
$\mathrm{C}^{2}$ & 4.396 & 1 & 4.396 & 21.07 & 0.0025 \\
Model & 103.10 & 9 & 11.46 & 54.93 & $<0.0001$ \\
Error & 0.054 & 2 & 0.0269 & &
\end{tabular}



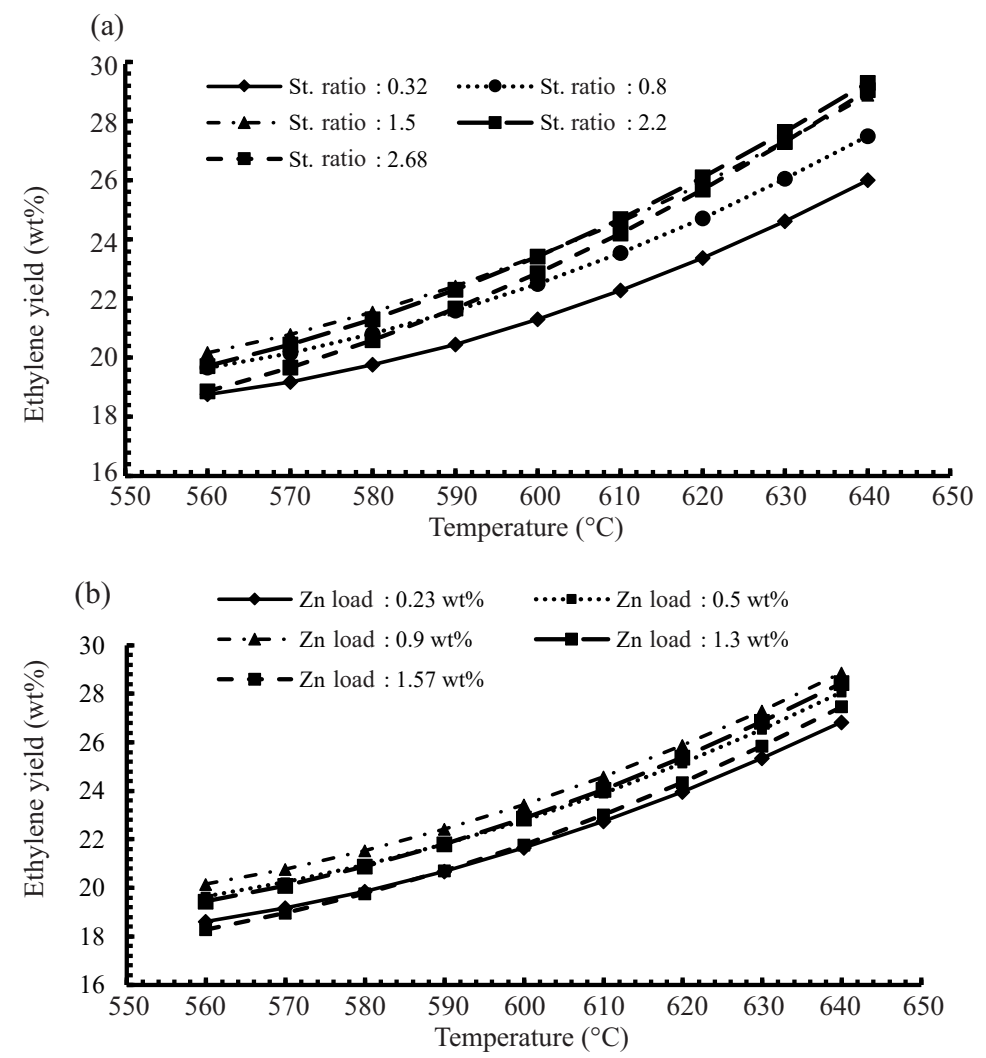

Fig. 4. Effect of temperature on the model predicted ethylene yield in a variety of (a) steam ratios at the constant $\mathrm{Zn}$ loading $0.9 \mathrm{wt} \%$ and (b) $\mathrm{Zn}$ contents in the catalyst at the constant steam ratio 1.5 of the feed.
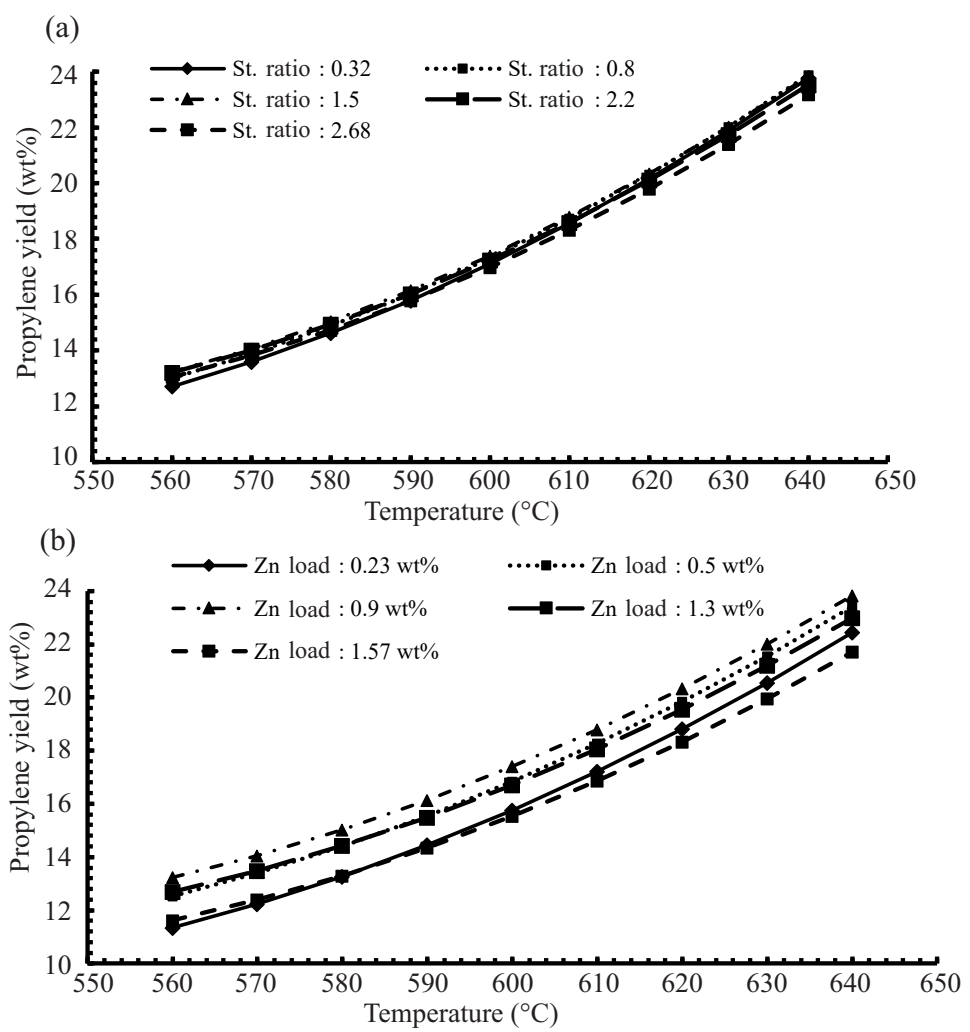

Fig. 5. Effect of temperature on the model predicted propylene yield in a variety of (a) steam ratios at the constant $\mathrm{Zn}$ loading $0.9 \mathrm{wt} \%$ and (b) $\mathrm{Zn}$ contents in the catalyst at the constant steam ratio 1.5 of the feed. 
comparison to temperature. Moreover, Figs $4 \mathrm{~b}$ and $5 \mathrm{~b}$ illustrate the effect of temperature on olefin yields for different $\mathrm{Zn}$ loadings in the catalyst at the constant 1.5 ratio of steam over LPG. For both olefin yields, $\mathrm{Zn}$ loading $0.9 \mathrm{wt} \%$ showed better performance. As shown, the olefin yields increased with the temperature, not depending on $\mathrm{Zn}$ loading ( $\mathrm{wt} \%$ ) and steam ratio values. Since the cracking reaction is endothermic and must provide the activation energy for the reactant, the higher temperature is in favour of the process. However, higher temperature increases coke formation to a great extent. The results demonstrate that the ethylene and propylene yields are in the range of $18-29 \%$ and $11-24 \%$, respectively.

Figures 6 and 7 present the model predicted yields of ethylene and propylene, respectively, for different waterfeed ratios. Figures $6 a$ and $7 \mathrm{a}$ illustrate the effect of the added steam flow on olefin yields for different reaction temperatures at the constant $0.9 \mathrm{wt} \%$ of $\mathrm{Zn}$ loading. For both olefin yields, the highest temperature, $634^{\circ} \mathrm{C}$, showed better performance. Moreover, Figs $6 \mathrm{~b}$ and $7 \mathrm{~b}$ illustrate the effect of a mild steam flow on olefin yields for different $\mathrm{Zn}$ loadings over HZSM-5 at the reaction temperature of $600{ }^{\circ} \mathrm{C}$. For both olefin yields, $\mathrm{Zn}$ loading of $0.9 \mathrm{wt} \%$ showed better performance. Regarding the steam ratio, as illustrated in Figs 6 and 7, it had the most significant contribution in the range of 1.5 to 2.2 for the ethylene yield and of 1 to 1.8 for the propylene yield.

A small amount of steam is in favour of catalytic cracking reactions, by reason of its performance as an oxidative to remove the coke precursor that drops the rate of catalyst deactivation [24,25]. Furthermore, steam plays an indispensable role in decreasing bimolecular reactions in catalytic cracking, such as hydrogen transfer to form heavy products [26-29]. On the contrary, raising the amount of steam from the optimum range to the higher levels accelerates the loss of active sites in the structure, which is indicative of sintering deactivation. It should be noted that it causes a high dealumination rate that finally decreases the acidic sites for the occurring reactions [30].

Figures 8 and 9 present the model predicted yields of ethylene and propylene, respectively, for different $\mathrm{Zn}$ loadings over HZSM-5. Figures 8a and 9a illustrate the effect of zinc loading on olefin yields for different reaction temperatures at the constant 1.5 steam ratio. For both olefin yields, the highest temperature, $634{ }^{\circ} \mathrm{C}$, showed better performance. Moreover, Figs $8 \mathrm{~b}$ and $9 \mathrm{~b}$ illustrate the effect of loading of zinc over catalyst performance for different steam ratios at the reaction temperature of $600{ }^{\circ} \mathrm{C}$. For both olefin yields, the 1.5 steam ratio showed better performance. As regards the zinc weight percentage for catalyst modification, it had better performance in the
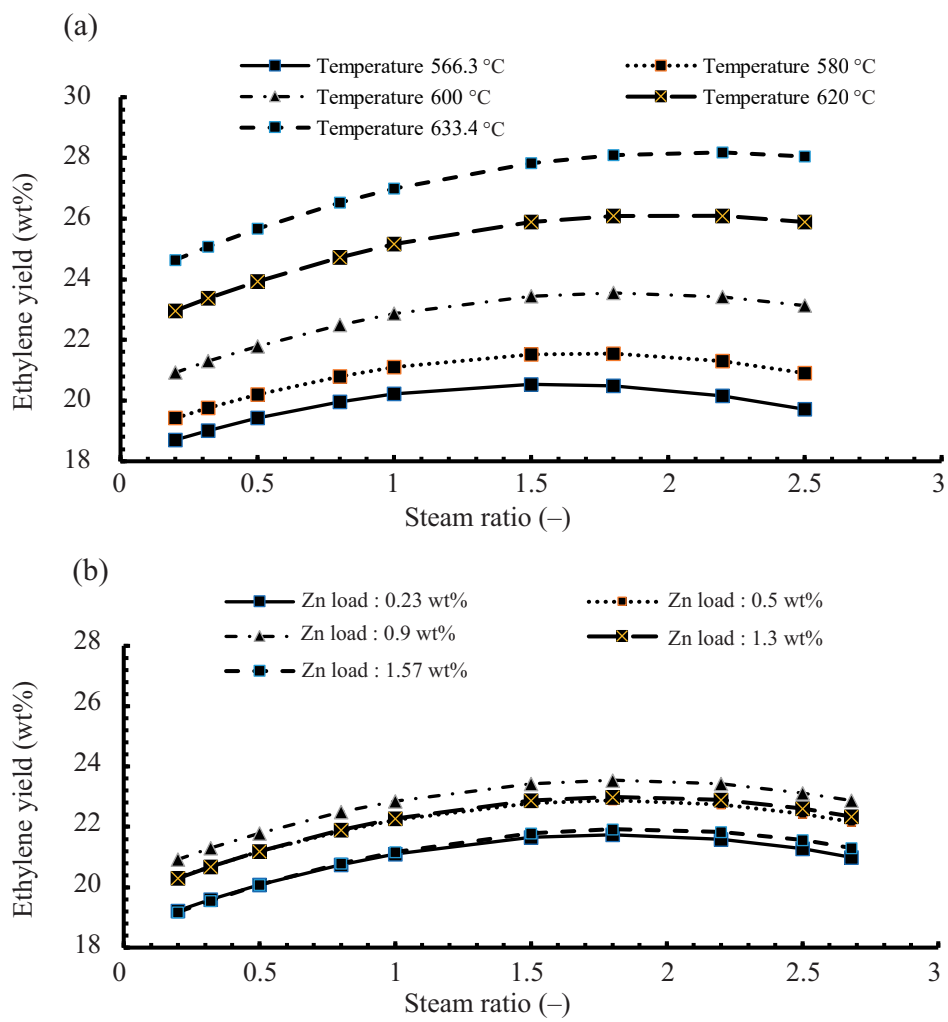

Fig. 6. Effect of steam ratio on the model predicted ethylene yield in a variety of (a) temperatures at the constant $\mathrm{Zn}$ loading $0.9 \mathrm{wt} \%$ and (b) $\mathrm{Zn}$ contents in the catalyst at the constant temperature $600{ }^{\circ} \mathrm{C}$. 

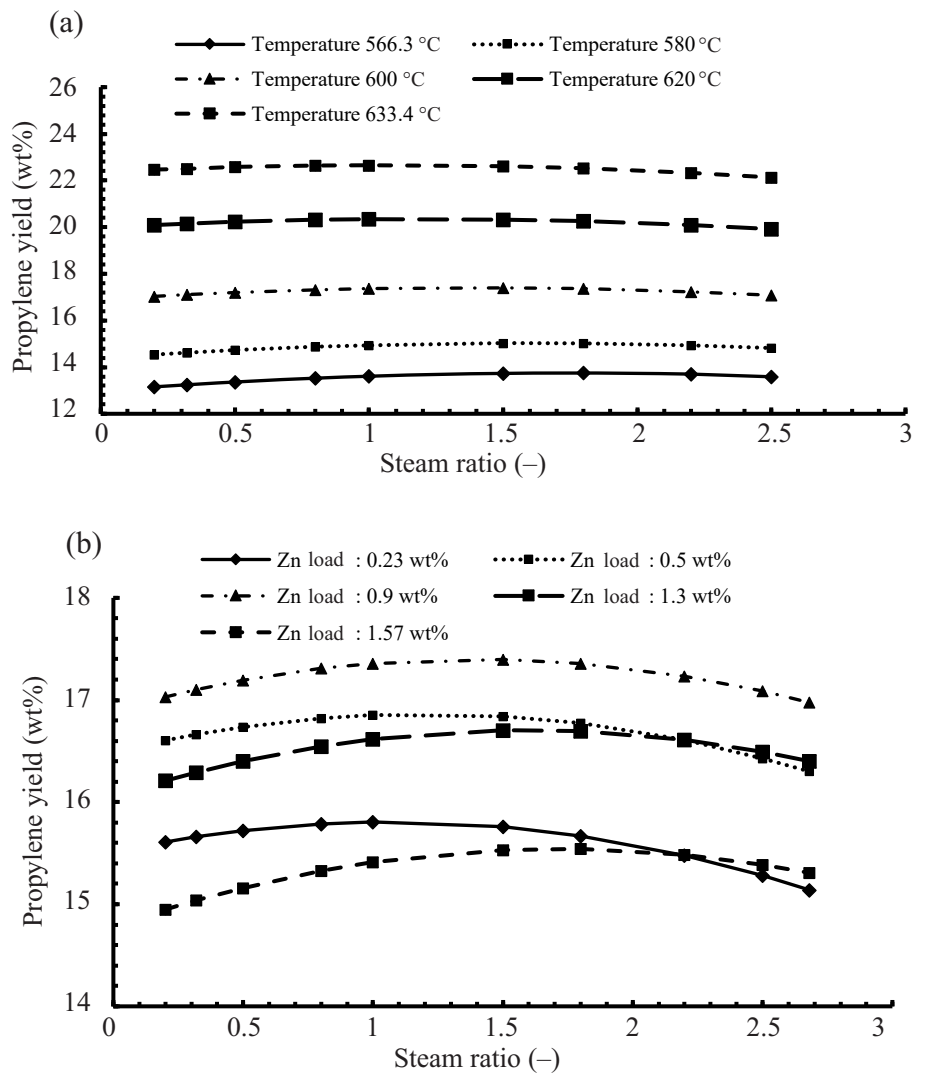

Fig. 7. Effect of steam ratio on the model predicted propylene yield in a variety of (a) temperatures at the constant $\mathrm{Zn}$ loading $0.9 \mathrm{wt} \%$ and (b) $\mathrm{Zn}$ contents in the catalyst at the constant temperature $600{ }^{\circ} \mathrm{C}$.
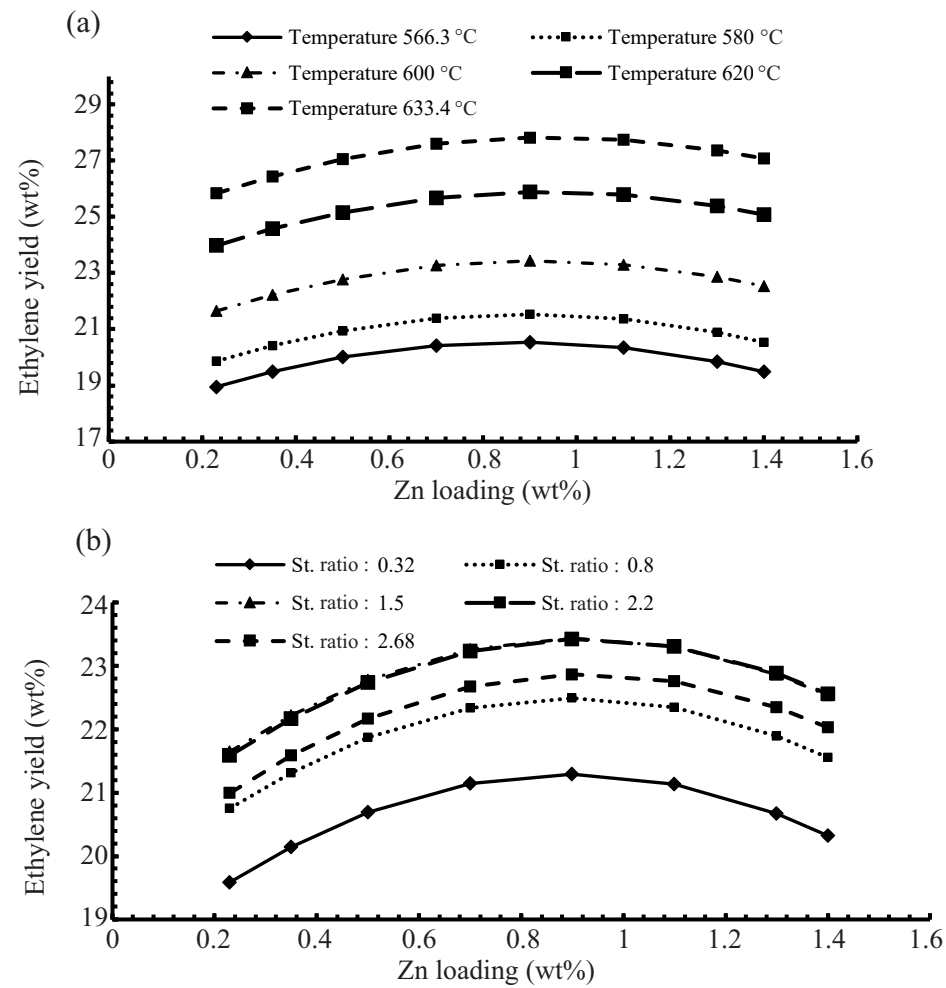

Fig. 8. Effect of $\mathrm{Zn}$ loading on ethylene yield in a variety of (a) temperatures at the constant steam ratio 1.5 and (b) steam ratios at the constant temperature $600{ }^{\circ} \mathrm{C}$. 

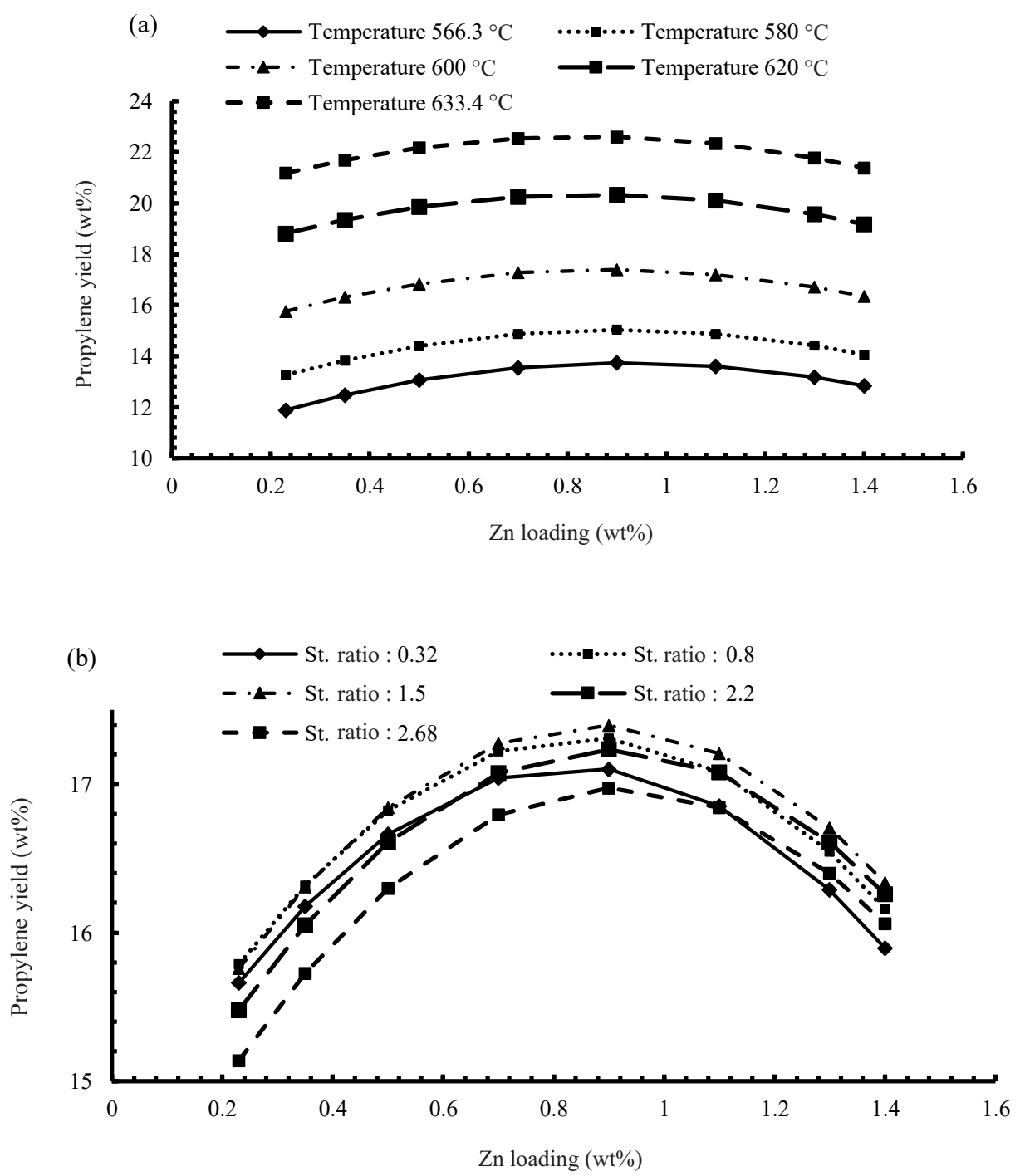

Fig. 9. Effect of $\mathrm{Zn}$ loading on propylene yield in a variety of (a) temperatures at the constant steam ratio 1.5 and (b) steam ratios at the constant temperature $600{ }^{\circ} \mathrm{C}$.

range of 0.7 to $1.1 \mathrm{wt} \%$ for the light olefin yield, as depicted in Figs 8 and 9.

HZSM-5 is a catalyst with a high density of Bronsted and Lewis acid sites, where the reactant adsorbs onto the active sites and then the reactions progress. These acidic sites are sufficiently strong to be the host of heavier side products and a coke precursor. In most cases the acidic sites must be diluted by a transition metal to decline the acidic properties.

Based on the Plank-Hirschler mechanism, upon loading cations over acidic HZSM-5, $\mathrm{H}^{+}$is omitted and the number of acidic sites is decreased. Thus, due to the relatively high electrostatic potential of cations like $\mathrm{Zn}^{2+}$, a few new Bronsted acid sites were formed during the ionexchange process [31]. It seems that the incorporated $\mathrm{Zn}$ species are replaced in part by the former strong acid sites, and they formed a kind of stronger new acid sites. The incorporated $\mathrm{Zn}$ species along with the Bronsted acid sites act like a Lewis acid site because of [Al-O-Zn-O-Zn-O-Al] or [Al-O-Zn-O-Al] species formation [10,32,33]. Moreover, zinc oxide can reduce the active site blockage resulting from the large intermediates from cracking reactions, which occurs because $\mathrm{Zn}$ species can create more Lewis acid sites near the Bronsted acid sites [19,20]. However, by decreasing the number of stronger acid sites upon zinc impregnation, the coke formation would be limited and consequently the activity of the catalyst will be preserved [10]. It is detected that introducing more than the optimum amount of zinc as an intermediate metal to the catalyst results in decreasing the Bronsted strong acid sites, though maintaining a sufficiently high number to diminish the protolytic cracking reactions [24,34]. 


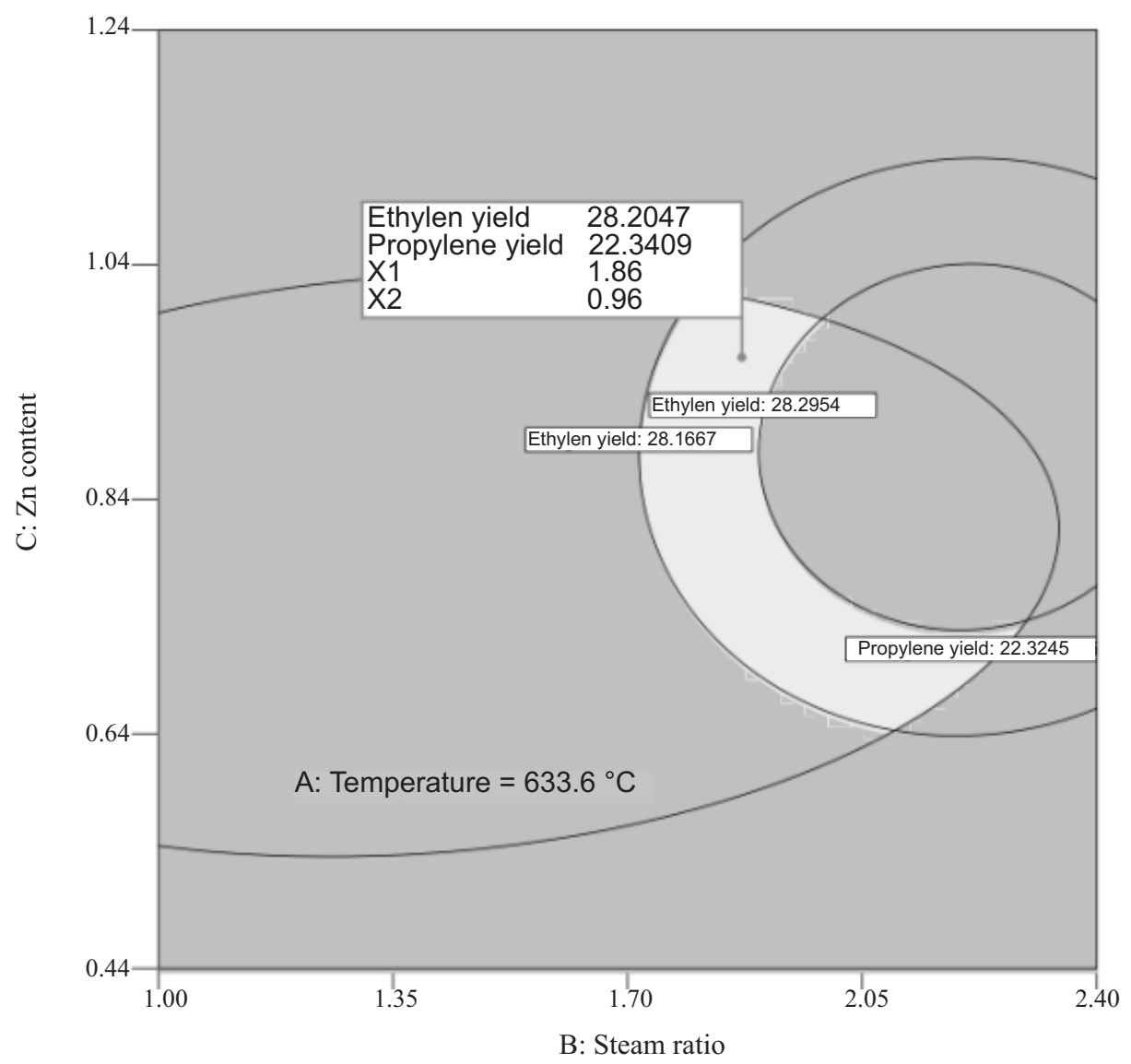

Fig. 10. Overlay plot for the optimum region at the temperature $633.6{ }^{\circ} \mathrm{C}$ and with different zinc contents (wt\%) and steam ratios in the feed; the shaded zone indicates the maximum obtained ethylene and propylene yields (wt $\%)$; standard uncertainties (u) are $\mathrm{u}(\mathrm{T})= \pm 0.1^{\circ} \mathrm{C}, \mathrm{u}($ Steam ratio $)= \pm 0.01, \mathrm{u}(\mathrm{Zn}$ content $)= \pm 0.01 \mathrm{wt} \%$, $\mathrm{u}$ (Yield $)= \pm 0.01 \mathrm{wt} \%$; "Design-Expert 11 software output".

Graphical optimization has produced an overlay plot to display the area of feasible response values in the factor space. The shaded part, which indicates the value of possible response areas in the factor space and graphical optimization, is shown in Fig. 10. Two responses, the ethylene and propylene yields, determine the optimum region, shown in light grey colour. Model validations at experimental combinations were used for validation of the statistical model. Under these conditions, the experimental response for the ethylene yield was $28.20 \mathrm{wt} \%$ and the response for the propylene yield was $22.34 \mathrm{wt} \%$. As illustrated in Fig. 10, the optimum set was $633.6{ }^{\circ} \mathrm{C}$ for temperature, 1.86 for water/LPG ratio and $0.96 \mathrm{wt} \%$ for $\mathrm{Zn}$ loading over the HZSM-5 catalyst. A parity plot for product yields in Fig. 11 indicates an acceptable agreement between the experimental and model-fitted values over the range of the operating conditions used in this study. The objective function parameters were obtained with root mean square $1.94 \%$ and $1.71 \%$ for ethylene and propylene yields, respectively.

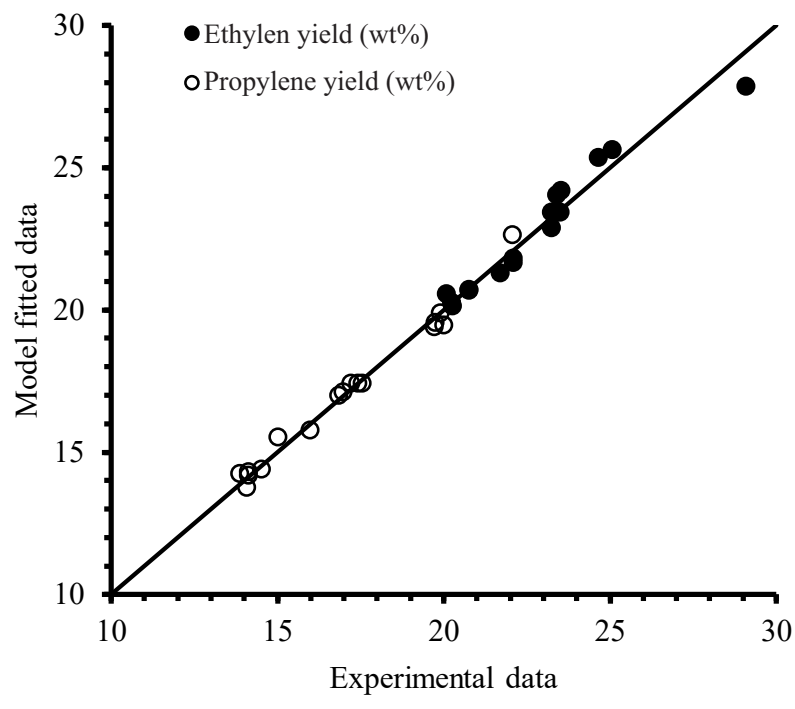

Fig. 11. Comparison between the experimental data and modelpredicted data for ethylene and propylene yields at different temperatures $\left(566,580,600,620,634^{\circ} \mathrm{C}\right)$, zinc contents $(0.18$, $0.4,0.72,1.04,1.26 \mathrm{mg})$ and water flows in the feed $(2.6,6.4$, $12,17.6,21.4 \mathrm{cc} / \mathrm{min})$. 


\section{CONCLUSIONS}

In this study, a CCD was employed to investigate the effects of water, zinc loading, and temperature with regard to ethylene and propylene yields. It was detected that there was an optimum point for the initial ethylene and propylene yields by specified values of $\mathrm{Zn}$ loading and steam ratio of the feed. The RSM showed that the significant second-order equation with an appropriate $\mathrm{R}^{2}(>0.95)$ was fitted for the ethylene and propylene yields as the function of independent factors. It was concluded that the RSM can determine the optimal set temperature $633.6{ }^{\circ} \mathrm{C}$, steam ratio 1.86 and $\mathrm{Zn}$ loading $0.96 \mathrm{wt} \%$ to obtain the best result for the initial yields of propylene and ethylene.

\section{ACKNOWLEDGEMENTS}

The authors appreciate the support from the School of Engineering, Virumaa College of Tallinn University of Technology and from the Department of Chemical Engineering of Tarbiat Modares University, and are thankful to Stat-Ease, Minneapolis, MN, USA, for the provision of Design-Expert 11 Package. The publication costs of this article were covered by the Estonian Academy of Sciences.

\section{REFERENCES}

1. Mohiuddin, E., Mdleleni, M. M. and Key, D. Catalytic cracking of naphtha: The effect of $\mathrm{Fe}$ and $\mathrm{Cr}$ impregnated ZSM-5 on olefin selectivity. Appl. Petrochem. Res., 2018, 8, 119-129.

2. Barghi, B. and Karimzadeh, R. Modeling of ZnZSM-5 deactivation during liquefied petroleum gas catalytic cracking in the presence of steam. React. Kinet. Mech. Catal., 2017, 120(2), 753-773.

3. Barghi, B. and Karimzadeh, R. Kinetic modeling based on complex reaction theory for $\mathrm{n}$-butane catalytic cracking over HZSM-5. React. Kinet. Mech. Catal., 2015, 116, 507522.

4. Gu, B., Zhou, C., He, S., Moldovan, S., Chernavskii, P. A., Ordomsky, V. V. et al. Size and promoter effects on iron nanoparticles confined in carbon nanotubes and their catalytic performance in light olefin synthesis from syngas. Catal. Today, 2020, 357, 203-213.

5. Narasimharao, K. and Alshehri, A. Gold supported yttrium oxide nanorods for catalytic oxidative cracking of $n$-propane to light olefins. Fuel, 2020, 278, 118375.

6. Urata, K., Furukawa, S. and Komatsu, T. Location of coke on H-ZSM-5 zeolite formed in the cracking of $n$-hexane. Appl. Catal. A-Gen., 2014, 475, 335-340.

7. Ishihara, A., Ninomiya, M., Hashimoto, T. and Nasu, H. Catalytic cracking of $\mathrm{C} 12-\mathrm{C} 32$ hydrocarbons by hierarchical $\beta$ - and Y-zeolite-containing mesoporous silica and silica- alumina using Curie point pyrolyzer. J. Anal. Appl. Pyrolysis, 2020, 150, 104876.

8. Liu, W., Liu, X., Gu, Y., Liu, Y., Yu, Z., Lyu, Y. et al. A new composite consisting of $\mathrm{Y}$ zeolite and $\mathrm{ZrO}_{2}$ for fluid catalytic cracking reaction. Compos. B. Eng., 2020, 200, 108317.

9. Ji, Y., Yang, H., Zhang, Q. and Yan, W. Phosphorus modification increases catalytic activity and stability of ZSM-5 zeolite on supercritical catalytic cracking of ndodecane. J. Solid State Chem., 2017, 251,7-13.

10. Wang, X., Gao, X., Dong, M., Zhao, H. and Huang, W. Production of gasoline range hydrocarbons from methanol on hierarchical ZSM-5 and Zn/ZSM-5 catalyst prepared with soft second template. J. Energy Chem., 2015, 24(4), 490496.

11. Wattanapaphawong, P., Reubroycharoen, P., Mimura, N., Sato, O. and Yamaguchi, A. Effect of carbon number on the production of propylene and ethylene by catalytic cracking of straight-chain alkanes over phosphorus-modified ZSM5. Fuel Process. Technol., 2020, 202, 106367.

12. Zhang, C., Kwak, G., Lee, Y.-J., Jun, K.-W., Gao, R., Park, H.-G. et al. Light hydrocarbons to BTEX aromatics over Zn-modified hierarchical ZSM-5 combined with enhanced catalytic activity and stability. Microporous Mesoporous Mater., 2019, 284, 316-326.

13. Wang, L., Lei, H., Bu, Q., Ren, S., Wei, Y., Zhu, L. et al. Aromatic hydrocarbons production from ex situ catalysis of pyrolysis vapor over Zinc modified ZSM-5 in a packed-bed catalysis coupled with microwave pyrolysis reactor. Fuel, 2014, 129, 78-85.

14. Ni, Y., Sun, A., Wu, X., Hai, G., Hu, J., Li, T. et al. Preparation of hierarchical mesoporous Zn/HZSM-5 catalyst and its application in MTG reaction. J. Nat. Gas Chem., 2011, 20(3), 237-242.

15. Wang, X., Zhang, X. and Wang, Q. N-dodecane hydroisomerization over Pt/ZSM-22: Controllable microporous Brönsted acidity distribution and shape-selectivity. Appl. Catal. A-Gen., 2020, 590, 117335.

16. Huyen, P. T., Trinh, V. D., Portilla, M. T. and Martínez, C. Influence of boron promotion on the physico-chemical properties and catalytic behavior of $\mathrm{Zn} / \mathrm{ZSM}-5$ in the aromatization of $n$-hexane. Catal. Today., 2021, 366, 97102.

17. Oseke, G. G., Atta, A. Y., Mukhtar, B., El-Yakubu, B. J. and Aderemi. B. O. Increasing the catalytic stability of microporous Zn/ZSM-5 with copper for enhanced propane aromatization. J. King Saud Univ. Eng. Sci., 2020.

18. Wei, Z., Chen, L., Cao, Q., Wen, Z., Zhou, Z., Xu, Y. et al. Steamed Zn/ZSM-5 catalysts for improved methanol aromatization with high stability. Fuel Process. Technol., 2017, 162, 66-77.

19. Wei, Y., Liu, Z., Wang, G., Qi, Y., Xu, L., Xie, P. et al. Production of light olefins and aromatic hydrocarbons through catalytic cracking of naphtha at lowered temperature. Stu. Surf. Sci. Catal., 2005, 158(B), 12231230.

20. Bezerra, M. A., Santelli, R. E., Oliveira, E. P., Villar, L. S. and Escaleira, L. A. Response surface methodology (RSM) as a tool for optimization in analytical chemistry. Talanta, 2008, 76(5), 965-977.

21. Chen, L., Hu, J., Lin, F., Cadigan, C., Cao, W., Qi, Z. et al. Self-assembled single-crystalline $\mathrm{ZnO}$ nanostructures. CrystEngComm., 2013, 15(19), 3780-3784. 
22. Bi, J., Liu, M., Song, C., Wang, X. and Guo, X. C2-C4 light olefins from bioethanol catalyzed by $\mathrm{Ce}$-modified nanocrystalline HZSM-5 zeolite catalysts. Appl. Catal. B, 2011, 107(1-2), 68-76.

23. Varzaneh, A. Z., Kootenaei, A. H. S., Towfighi, J. and Mohamadalizadeh, A. Optimization and deactivation study of $\mathrm{Fe}-\mathrm{Ce} / \mathrm{HZSM}-5$ catalyst in steam catalytic cracking of mixed ethanol/naphtha feed. J. Anal. Appl. Pyrolysis, 2013, 102, 144-153.

24. Akah, A., Williams, J. and Ghrami, M. An overview of light olefins production via steam enhanced catalytic cracking. Catal. Surv. from Asia, 2019, 23, 265-276.

25. Barghi, B., Fattahi, M. and Khorasheh, F. Kinetic modeling of propane dehydrogenation over an industrial catalyst in the presence of oxygenated compounds. React. Kinet. Mech. Catal., 2012, 107(1), 141-155.

26. Ghrib, Y., Frini-Srasra, N., Srasra, E., Martínez-Triguero, J. and Corma, A. Synthesis of cocrystallized USY/ZSM-5 zeolites from kaolin and its use as fluid catalytic cracking catalysts. Catal. Sci. Technol., 2018, 8(3), 716-725.

27. Nestler, H. C. Pyrolysis and steam cracking system. Google Patents US10280377, 7 May 2019.

28. Akah, A. Application of rare earths in fluid catalytic cracking: A review. J. Rare Earths, 2017, 35(10), 941-956.
29. Müller, S., Liu, Y., Kirchberger, F. M., Tonigold, M., Sanchez-Sanchez, M. and Lercher, J. A. Hydrogen transfer pathways during zeolite catalyzed methanol conversion to hydrocarbons. J. Am. Chem. Soc., 2016, 138(49), 15994 16003.

30. Barghi, B., Fattahi, M. and Khorasheh, F. The modeling of kinetics and catalyst deactivation in propane dehydrogenation over Pt-Sn $/ \gamma-\mathrm{Al}_{2} \mathrm{O}_{3}$ in presence of water as an oxygenated additive. Pet. Sci. Technol., 2014, 32(10), 1139-1149.

31. Tynjälä, P. and Pakkanen, T. T. Acidic properties of ZSM-5 zeolite modified with $\mathrm{Ba}^{2+}, \mathrm{Al}^{3+}$ and $\mathrm{La}^{3+}$ ion-exchange. J. Mol. Catal. A Chem., 1996, 110(2), 153-161.

32. Li, Y., Liu, S., Xie, S. and Xu, L. Promoted metal utilization capacity of alkali-treated zeolite: Preparation of Zn/ZSM-5 and its application in 1-hexene aromatization. Appl. Catal. A-Gen., 2009, 360(1), 8-16.

33. Almutairi, S. M. T., Mezari, B., Magusin, P. C. M., Pidko, E. A. and Hensen, E. J. M. Structure and reactivity of Zn-modified ZSM-5 zeolites: the importance of clustered cationic Zn complexes. ACS Catal., 2012, 2(1), 71-83.

34. Roshanaei, A. and Alavi, S. M. Kinetic study of propane aromatization over Zn/HZSM-5 zeolite under conditions of catalyst deactivation using genetic algorithm. J. Serbian Chem. Soc., 2018, 83(4), 473-488.

\title{
Vee ja tsingi mõju vedelgaasi katalüütilisele krakkimisele kergete olefiinide tootmisel, kasutades vastuspinnametoodikat
}

\author{
Bijan Barghi, Allan Niidu ja Ramin Karimzadeh
}

Veeldatud naftagaasi katalüütilise krakkimise optimeerimine on kerge olefiini tootmise üks põhiprobleeme. Uurimaks tsingi, vee ja temperatuuri mõju ZSM-5 jõudlusele, rakendati vastuspinnametoodikat, kasutades viie taseme ning kolme teguri keskset komposiitkonstruktsiooni. Tulemused näitasid, et algse propüleeni ja etüleeni saagise optimumi saavutamiseks tuleb tõsta ZSM-5 tsinkmetalliga impregneerimise temperatuuri $\left(566-634^{\circ} \mathrm{C}\right)$ ja tsingi kontsentratsiooni $(0,23-$ $1,57 \mathrm{wt} \%$ ) ning vee/LPG suhet (vahemikus $0,32-2,68$ ), mis on vastavalt $22,34 \mathrm{wt} \% \mathrm{ja} 28,20 \mathrm{wt} \%$. Katseandmed sobitati rahuldavalt ruutmudelitega, kasutades töötingimuste vahemikus mitmekordset regressioonanalüüsi. Vastuspinnametoodika abil määrati optimaalsed tsingiga impregneerimise tingimused: tsingi massiosa $(0,96 \mathrm{wt} \%)$, vee/vedelgaasi suhe $(1,86)$ ja temperatuur $\left(633,6{ }^{\circ} \mathrm{C}\right)$. Etüleeni ja propüleeni saagiste vastuste F-väärtused olid ruutmudelis vastavalt 15,08 ja 54,93. Seega olid leitud mudelid sobivad. 